\title{
Study on working peculiarities of glue laminated beams under conditions of slanting bending
}

\author{
Svyatoslav Gomon ${ }^{1}$, Andriy Pavluk ${ }^{2}$ \\ National University of Water Management and Environmental Engineering \\ 11, Soborna Street, Rivne, Ukraine, 33000 \\ 's.s.homon@nuwm.edu.ua, orcid.org/0000-0003-2080-5650 \\ 2pavluk andriy@ukr.net, orcid.org/0000-0003-3958-0519
}

The manuscript was received on 26.03.2017 and was accepted after revision for publication on 03.10.2017 DOI: $10.26884 / 1707.1801$

\begin{abstract}
Current rules do not take into account the peculiarities of glue laminated beams under the conditions of slanting bending. In fact, the rules do not consider the real change in the stress-strain behavior of such elements upon the load change from its initial application till fracture under the conditions of slanting bending due to the fact that material (wood) behavior in the construction is currently assumed as nominally elastic. What is more, this issue is not sufficiently studied either theoretically or experimentally.

This article is devoted to the study of the working peculiarities of glue laminated beams made of glued pine boards under the conditions of slanting bending.
\end{abstract}

The main issues are as follows, the description of research methodology and experimental prototypes, analysis and processing of the research results, working peculiarities of the material as part of the glue laminated wooden beams under the conditions of slanting bending.

The article presents the results of experimental studies on the bearing capacity and deformity of glue laminated beams under the conditions of slanting bending. The results will give the opportunity to design wooden constructions taking into account the profound knowledge on material capacity as well as the working peculiarities of its components, which will lead to a more practical cross section of structural components.

Investigation of the process of laminar deformation upon the section height and indication of the peculiarities of the stress-strain behavior of these layers due to the stress of physical force un-

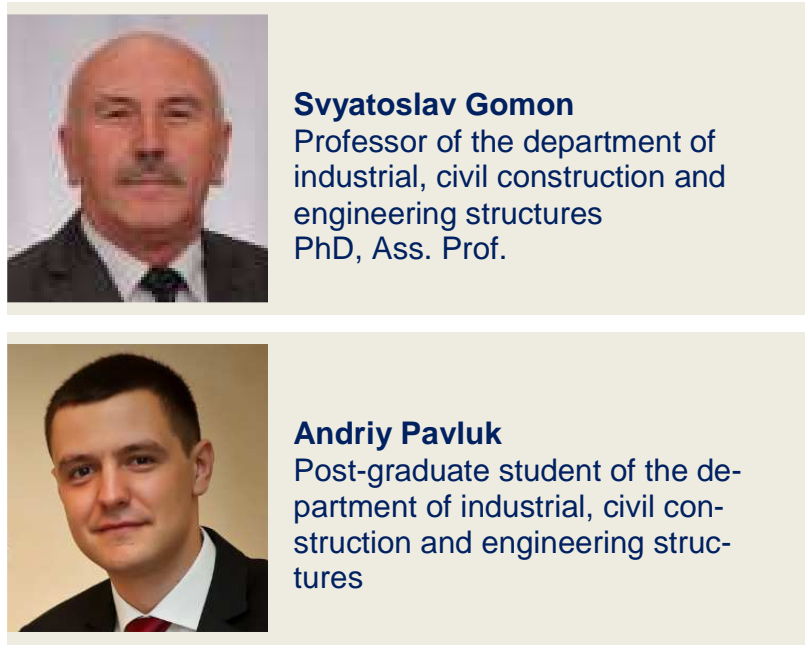

der the conditions of slanting bending will allow to perform more reliable calculations of stress-strain behavior and design of glue laminated beams at different stages.

Keywords: wood, bearing capacity, slanting bending, strain, stress, stiffness.

\section{INTRODUCTION}

Wood is not only one of the oldest construction materials, but also an important material to be used both in the present and future. Considerable increase in its use in the construction industry is an irresistible argument to this. Modern building wood has several benefits, such as light weight, easy manufacture, firmness and relatively cheap cost, constant 
natural renewability, which help to create new architectural forms. The appearance of laminated wooden structures has significantly stimulated and diversified the scope of use of wood in construction. They are currently used for raising one-storied industrial and sports facilities as well as multi-storied residential and public buildings.

The behavior of solid beams as well as glue laminated beams which are under the conditions of slanting bending is currently poorly known. Operative rules and existing studies [1] do not address the real behavior of the beams under the conditions of slanting bending or make it impossible to establish the neutral line position and the stress-strain distribution of the cross section at various stages of loading the construction in general.

\section{PURPOSE AND METHODS}

The purpose of this research is the study of the working peculiarities of glue laminated beams under the conditions of unsymmetrical bending $[2,3]$.

Wood moisture content at the moment of manufacture of the samples was within $12 \%$, according to [7]. Glue laminated beams were manufactured from a set of seventh boards $3250 \mathrm{~mm}$ long with the section of $100 \times 150$ $\mathrm{mm}$. The study of the beams was carried out on the previously made experimental installation [8]. Metal supports provided the required slope angle for organizing the prototypes. The supports were made of steel $4 \mathrm{~mm}$ thick and were set in the places for the beams to rest on them as well as in the points of application of two concentrated loads. Loading of the beam was executed with the help of a hydraulic jack which was housed on a metal traverse. The base of the traverse amounted $900 \mathrm{~mm}$ which made $1 / 3$ of the experimental beam span. The load level was controlled with the help of a dynamometer which was marked in advance. The load was applied by degrees of $8 . .10 \%$ of the assumed devastating load taking into account the guidelines and requirements [9]. The scheme of the experimental installation and the location of the devices on the prototype are shown in Fig.1.

Pilot testing of a glue laminated block is the principle method for solving the specified problems.

Glue laminated wooden beams were made from first pine wood with due account for the requirements [4-6]. Class D3 resorcinol resin adhesive was used for gluing beams.

To reduce the impact of the rotational moment on the working peculiarities of the beam $[10,11]$ ties were organized in the points of load application.

Locking of the beam deformation was performed with the help of 6 PAO deflectometers and strain gauges. The latter were glued to the beam amid the span around the cross-section perimeter with BF-2 glue. The surface of the beam was polished and degreased prior to glu-

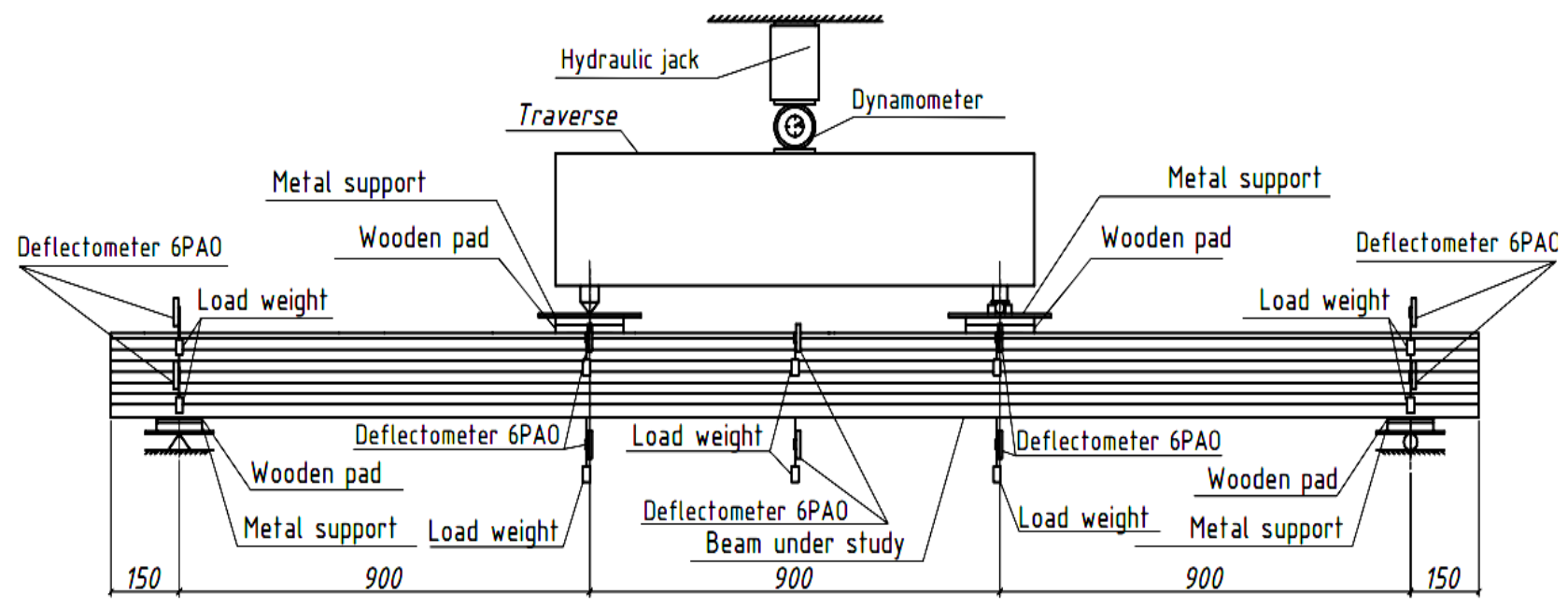

Fig.1. The scheme of the experimental installation and the location of the devices 
ing. Serviceability check of the strain gauges was performed in advance. The first check was performed prior to gluing by at ester; the second was performed after gluing and soldering by the computer software. The SIIT-3 straingauge station was responsible for sensor reading. Deflectometers were set on the supports in the points of load application and in the middle of the span to calculate deflections along the $\mathrm{Y}-\mathrm{Y}$ and Z-Z directions. All the devices that were used in the experiment were preliminary approved by the State certification licensing authority.

The values of deflection of the beams were recorded prior to the load application which ranged to $80 \%$ of the assumed devastating load since further load application could lead to immediate fracture of the prototypes and, consequently, to the eventual fracture of the measurement instrumentation.

\section{RESULTS}

Laminated wooden beams GLB-1 and GLB-2 were tested at the slope angle of $10^{\circ}$, GLB-3 and GLB-4 beams were tested at the slope angle of $25^{\circ}$.

Five minute delay was permitted at each stage of the load application to take the readings from all devices.

During the experiment, control was executed over the level of load application permit- ting critical deflection values $[12,13]$. According to [12], the maximum allowed deflection of the beams is $1 / 150 l$, where $l$ is the span of a beam. In our experiment, the maximum allowed deflection of the beams is as follows:

$$
w_{f i n}=\frac{l}{150}=\frac{2700}{150}=18 \mathrm{~mm}
$$

In the first place, the deflections along the Y-Y and Z-Z directions were calculated [13].

Afterwards load-strain diagrams were drawn, which were calculated by the formula:

$$
w=\sqrt{w_{y}^{2}+w_{z}^{2}}
$$

where: $w_{Y}$ is the deflection along the Y-Y direction, $\mathrm{mm}$; $w_{Z}$ is the deflection along the $\mathrm{Z}-\mathrm{Z}$ direction, $\mathrm{mm}$.

As reflected by the graph (Fig.2), at different slope angles the critical deflection was achieved at different values of the moment. The critical deflection for GLB-1 and GLB-2 beams occurred at 7,2 $\mathrm{kNm}$ and $8,28 \mathrm{kNm}$ moment, while for GLB-3 and GLB-4 beams at $10,35 \mathrm{kNm}$ and $10,8 \mathrm{kNm}$ respectively. This can be explained by a greater slope angle of the beam, since the secant line of the force direction creates the cross-section which is vertically more expanded at a slope angle of $25^{\circ}$ in comparison with the cross section at a slope angle of $10^{\circ}$.

All prototype beams GLB-1 - GLB-4 frac-

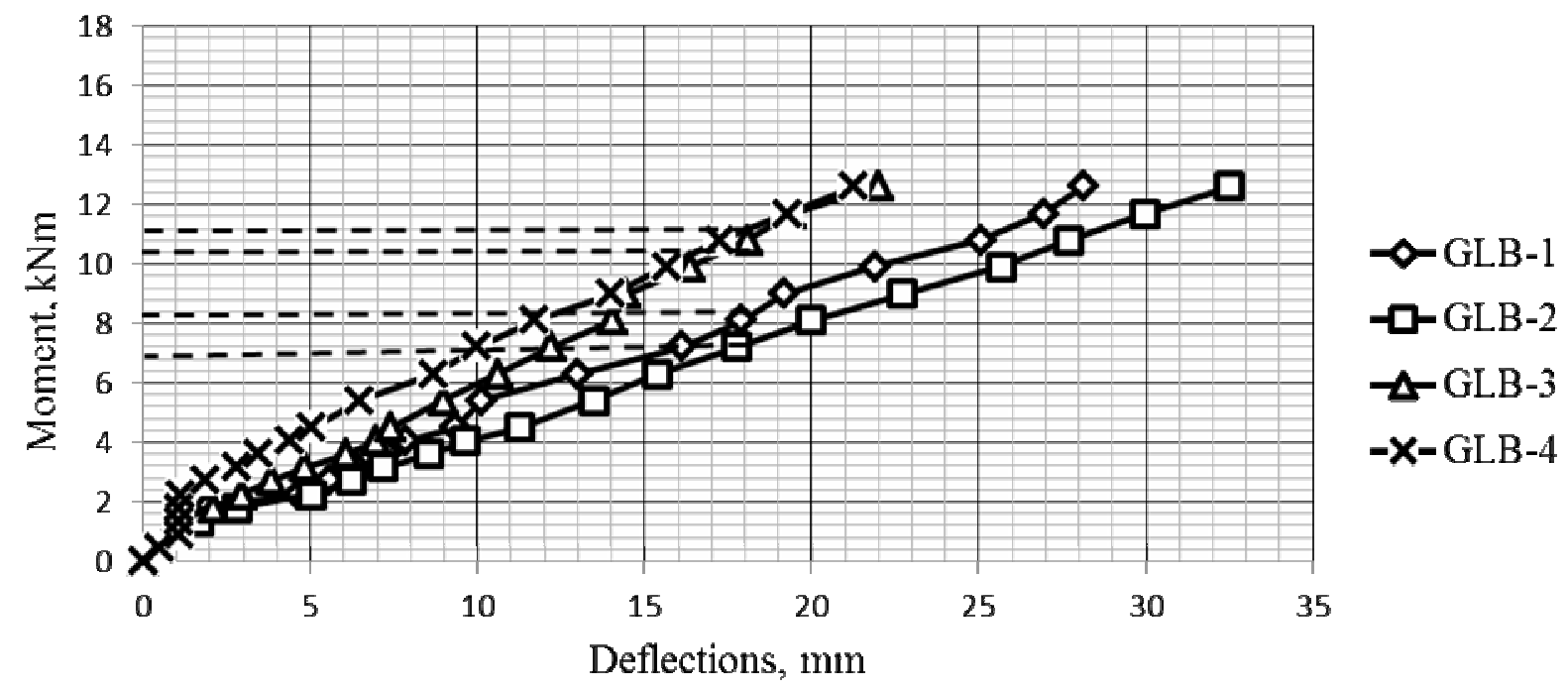

Fig.2. The full-scale deflections of glue laminated beams 
tured in the area of pure bending and so did the beams at direct bending [14 - 17]. The first cracking of the beams occurred when tested at the slope angle of $10^{\circ}$ at $30 \mathrm{kN}$ moment, whereas at the slope angle of $25^{\circ}$ it occurred at $32 \mathrm{kN}$. Afterwards, the rapid increase in strain occurred under the further increase of the load application, which lead to fracture of the unit [18 - 22], which started from the marginal board in the area of pure bending and was followed by crack propagation towards the supports. The fracture behavior of the GLB-1 and GLB-3 beams is shown in Fig.3 and in Fig.4.

The breaking moment for glue laminated beams GLB-1 and GLB-2 at the slope angle of $10^{\circ}$ amounts $17,1 \mathrm{kNm}$ and $17,33 \mathrm{kN}$, while this figure amounts $17,55 \mathrm{kN}$ and $17,82 \mathrm{kN}$ accordingly for the GLB-3 and GLB-4 beams at a slope angle of $25^{\circ}$.

The position of the neutral line at different levels of stress in a normal section in the area of pure bending of the askew-bended elements made from glue laminated wood was also determined by means of linear interpolation of the sensor readings. This method of determining the neutral line is the most conventional.

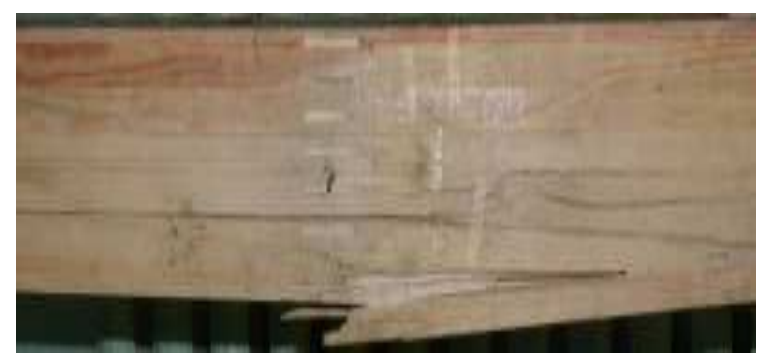

Fig.3. Fracture of the GLB-1

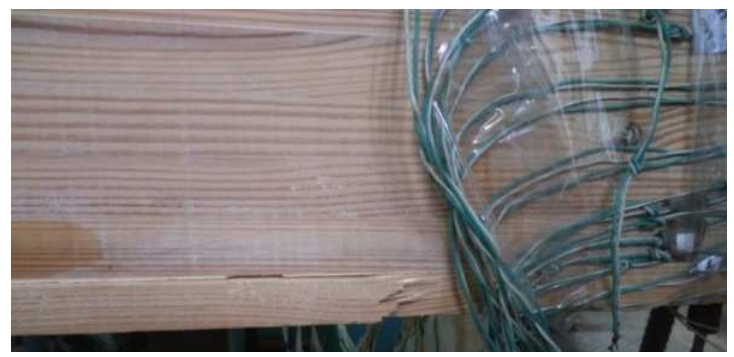

Fig.4. Fracture of the GLB-3
The neutral line of all the prototype glue laminated wooden beams changed its position towards increasing the area of the compressed zone under the increased load, simultaneously its slight twisting could be observed. The position of the neutral line for GLB-1 and GLB-3 beams under the different load levels are shown in Fig.5 and in Fig.6.

On processing the results obtained from the strain gauges, the deformation diagram was carried out for the deformation of the layers of wood in both the compressed and stretched areas of the prototype beams under the loads accommodation from the start of the load application and towards the loads on the verge of fracture while working under the conditions of slanting bending at the slope angles of $10^{\circ}$ and $25^{\circ}$.

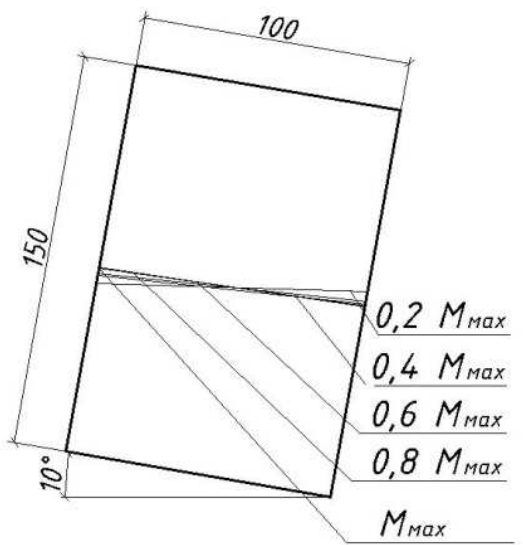

Fig.5. Change in the position of the neutral line of the GLB-1

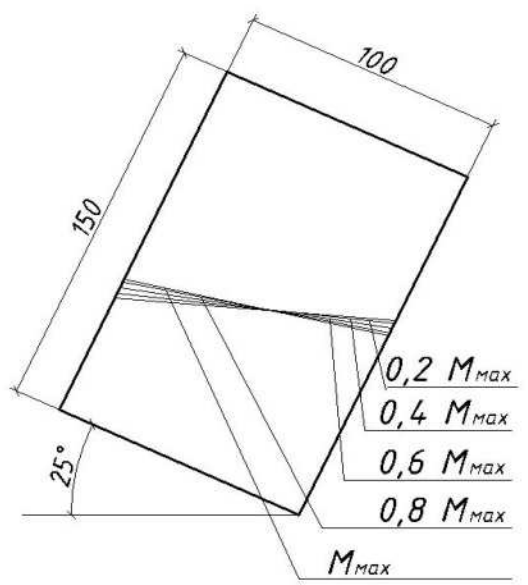

Fig.6. Change in the position of the neutral line of the GLB-3 

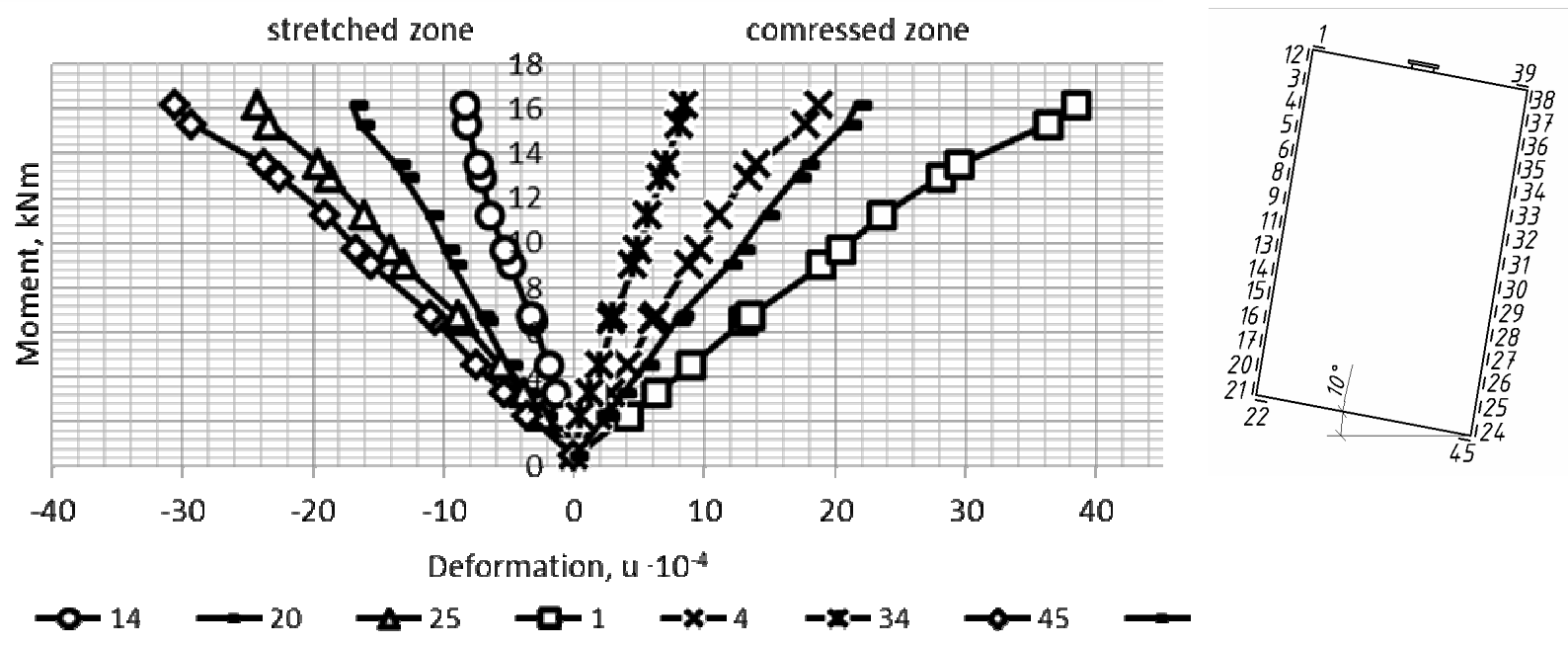

Fig.7. The diagram of GLB-1 deformation under the unsymmetrical bending at a slope angle of $10^{\circ}$
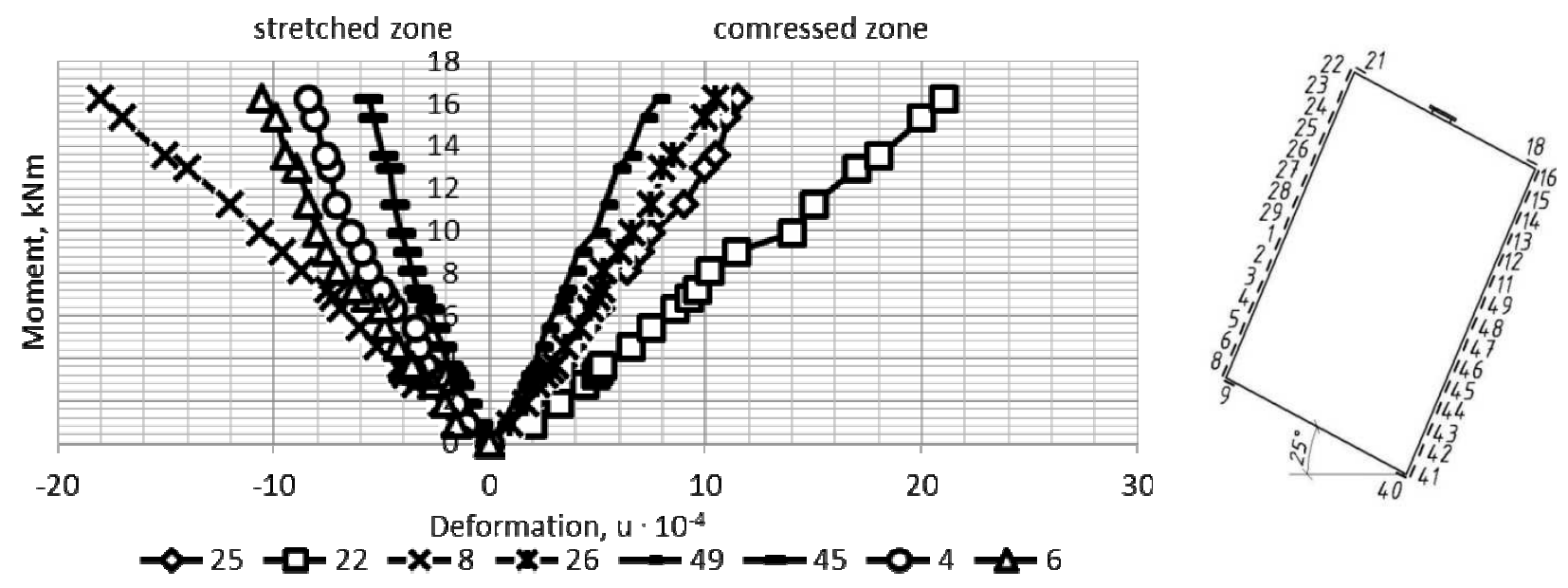

Fig.8. The diagram of GLB-3 deformation under the unsymmetrical bending at a slope angle of $25^{\circ}$

These graphs are shown in Fig.7 and in Fig.8. The number of strain gauges and their location on glue laminated beams are indicated to the right of the diagrams.

Deflectometers were positioned in the areas of load application in order to determine the value of the modulus of elasticity of glue laminated beams $[16,23]$. The modulus of elasticity was calculated according to the formula:

$$
E_{x}=\frac{F \cdot l^{3}}{548 \cdot l \cdot\left(w_{c}-w_{r}\right)}
$$

where $F-$ is the load affecting the beam, $\mathrm{kN}$; $l-$ is the calculated span of the beam, m;

$I$ - is the cross-sectional moment of inertia of the prototype beam, $\mathrm{m}^{3}$;

$w_{C}$ - is the beam deflection in the middle of the span, $\mathrm{mm}$;

$w_{N}-$ is the beam deflection at the point of load application, $\mathrm{mm}$.

The values of the elastic modulus at different levels of load application are shown in Table 1.

The elastic modulus of the glue laminated wood for GLB-1 beam amounted $13814 \mathrm{MPa}$, for GLB-2 beam - $13945 \mathrm{MPa}$. 
Table.1. The elastic modulus of the beams at different load application levels

\begin{tabular}{|c|c|c|}
\hline \multirow{2}{*}{ Beam } & $\begin{array}{c}\text { Load Applica- } \\
\text { tion Level }\end{array}$ & $\begin{array}{c}\text { Elastic Modu- } \\
\text { lus, E, MPa }\end{array}$ \\
\hline GLB-1 & $0,2 \mathrm{M}_{\text {мах }}$ & 18476 \\
\cline { 2 - 3 } & $0,4 \mathrm{M}_{\text {мах }}$ & 14105 \\
\cline { 2 - 3 } & $0,6 \mathrm{M}_{\text {мах }}$ & 12091 \\
\cline { 2 - 3 } GLB-2 & $0,8 \mathrm{M}_{\text {мах }}$ & 10585 \\
\hline & $0,2 \mathrm{M}_{\text {мах }}$ & 18363 \\
\cline { 2 - 3 } & $0,4 \mathrm{M}_{\text {мах }}$ & 14367 \\
\cline { 2 - 3 } & $0,6 \mathrm{M}_{\text {мах }}$ & 12364 \\
\cline { 2 - 3 } & $0,8 \mathrm{M}_{\text {мах }}$ & 10689 \\
\hline
\end{tabular}

\section{CONCLUSIONS}

On the basis of experimental works the following conclusions can be drawn:

- the moment of fracture for glue laminated beams GLB-1 and GLB-2 at the slope angle of $10^{\circ}$ amounted $17,1 \mathrm{kNm}$ and $17,33 \mathrm{kN}$, for GLB-3 and GLB-4 beams at the slope angle of $25^{\circ}-17,55 \mathrm{kN}$ and $17,82 \mathrm{kN}$, respectively

- GLB-1 beam reached critical deflection values at the moment of $8.28 \mathrm{kNm}$, GLB-2 beam - at 7,2 kNm, GLB-3 beam - at 10,35 $\mathrm{kNm}, \mathrm{GLB}-4$ beam - at 10,8 kNm;

- the value of the elastic modulus of the GLB-1 amounts $13814 \mathrm{MPa}$, for GLB-2 $13945 \mathrm{MPa}$;

- fracture behavior of the glue laminated wooden beams under the unsymmetrical bending at the slope angles of $10^{4}$ and $25^{\circ}$ was determined;

- the position of the neutral line of the beams under the slanting bending was determined and the method of its defining was suggested;

- the change in position of the neutral line of the askew-bended beams at the slope angles of $10^{\circ}$ and $25^{\circ}$ from the initial load application till fracture was specified.

\section{REFERENCES}

1. Sukach M.K., 2015. First international scientifically-practical conference «Underwater tech- nologies, 2015».Underwater technologies, Vol.01, 3-12 (in Ukrainian).

2. Darkov A.V., Shpirko G.S., 1975. The resistance of materials. Moscow, Wysshaia Shkola, 260-280 (in Russian).

3. Fesik S.P., 1982.Reference book on the resistance of materials, Kiev, Budivelnyk, 280 (in Russian).

4. The national standard of Ukraine, 2003. DSTU EN 518: 2003 Construction timber. Assorting. Requirements for visual sorting standards on durability. Kyiv, 11 (in Ukrainian).

5. The national standard of Ukraine, 2010. DSTU] B V.2.6-151: 2010 Glue laminated wooden structures. General specifications. Kyiv, 21 (in Ukrainian).

6. The national standard of Ukraine, 2003. DSTU EN 336: 2003 Structural timber made of coniferous and poplar. Dimensions. Allowable deviations. Kyiv, 7 (in Ukrainian).

7. The national standard of Ukraine, 2008. DSTU 4922: 2008 Timber and timber products. Methods for determining the humidity. Kyiv, 12 (in Ukrainian).

8. Pavluk A.P., Gomon S.S., 2016. The methods of research work of solid and laminated wooden beams in terms of slanting bend. Resource effective materials, constructions, structures and buildings. Collected Works, Vol.32. Rivne, NUWMNRU, 231-236 (in Ukrainian).

9. The national standard of Ukraine, 2003. DSTU EN 380-2008 Timber construction. General guidance on test methods of static load application. Kiev, 8 (in Ukrainian).

10.Gomon S.S., Pavluk A.P., 2015. Work of the wooden beams in terms of slanting bend . Resource effective materials, constructions, structures and buildings. Collected Works, Vol.31, Rivne, NUWMNRU, 422-428 (in Ukrainian).

11.Gomon S.S., Pavluk A.P., Polishchuk M.V., 2016. The change of neutral line solid wood beams for slanting bend depending on the character leaning and applying loading. Purpose made buildings and structures: modern materials and constructions. Collected Works. Kyiv, 120-127 (in Ukrainian).

12.State Construction Norms of Ukraine, 2010. DBN V.2.6-161: 2010 Constructions of houses and buildings. Wooden constructions. Substantive provisions. Kyiv, 102 (in Ukrainian).

13. The national standard of Ukraine, 2003. DSTU B V.1.2-3: 2006 The system of providing the reliability and safety of construction projects. Deflections and displacements. Kyiv, 30 (in Ukrainian). 
14.Pavluk A.P., 2016. The working peculiarities of solid beams in terms of slanting bend. Modern technologies and calculation methods in construction. Collected Works, Vol.5, Lutsk, LNTU, 259-266 (in Ukrainian).

15.Sasovskyj, T.A., 2016. The stress-stain condition of the glue laminated beams under the lowcycle load regime. Thesis for the degree of $\mathrm{PhD}$. in technical science. Rivne, NUWMNRU, 103-105 (in Ukrainian).

16.Delova M.I., 2001. Deformation of bent glue laminated wooden elements under static loading. Thesis for the degree of Candidate of Technical Sciences. Kursk, KSTU, 97-107 (in Russian).

17.Surmay M.I., 2015. Firmness and deformability of the glue laminated beams with fiberglass and basalt reinforcement. Thesis for the degree of Candidate of Technical Sciences. Lviv, NULP, 52-56 (in Ukrainian).

18.Gomon S.S., Sasovskyj T.A., 2014. Research of the stress condition of bending wood elements using the full chart of deformation of the material.Resource effective materials, constructions, structures and buildings. Collected Works, Vol.27, Rivne, NUWMNRU, 62-67 (in Ukrainian).

19.Gomon S.S., Sasovskyj T.A., Yatsuk V.O. 2012. Definition of the stress-strain state of the normal section of the working peculiarities of wood onto the cross fold, taking into account the full diagram of deformation of the material. The problems of development of the urban environment.Collected Works, Vol.8, Kyiv, NAU, 66-72 (in Ukrainian).

20.Gomon S.S., Sasovskyj T.A., 2014. Work peculiarities of the bending elements made from glue laminated wood under the conditions of low-cycle loadings. Resource effective materials, constructions, structures and buildings.Collected Works, Vol.28, Rivne, NUWMNRU, 112-117 (in Ukrainian).

21.Gomon S.S., Sasovskyj T.A., 2016. Working peculiarities of bending elements made from glue laminated wood under the conditions of low-cycle loadings. Bulletin of the BelarusianRussian University, Vol.1(50), Mogilev, UPKP MEUP, 130-139 (in Russian).

22.Bilyk S.I., 2016. Determination of critical load of elastic steel column based on experimental data. Underwater technologies, Vol.04, 89-96.

23.Skoruk O.V., 2016. The strength and crack resistance fiber concrete slabs supported on four sides on repeated loads. Underwater technologies, Vol.03, 83-93 (in Ukrainian).

\section{Исследование работы балок из клееной древесины в условиях косого изгиба}

\section{Святослав Гомон, Андрей Павлюк}

Аннотация. Действующие нормы не учитывают особенностей работы балок из клееной древесины при косом изгибе. Также нормы не учитывают реальное изменение напряженнодеформированного состояния таких элементов при изменении нагрузки от начала приложения до разрушения в условиях косого изгиба, поскольку в настоящее время работа материала (древесины) в конструкциях принимается условно упругой, и кроме того, этот вопрос как теоретически, так и экспериментально еще недостаточно изучен.

Статья посвящена изучению особенностей работы деревянных балок из клееных сосновых досок при косом изгибе. Основными вопросами являются следующие: описание методики исследований опытных образцов, анализ и обработка полученных результатов исследований, изучение особенностей работы материала в составе дощатоклееных деревянных балок в условиях косого изгиба. В статье приведены результаты экспериментальных исследований несущей способности и деформативности балок из клееной древесины в условиях косого изгиба. Результаты позволят проектировать конструкции из древесины, используя более полный учет возможностей материала и особенностей работы элементов, что приведет к более экономному подбору поперечного сечения элементов конструкций.

Исследование процесса послойного деформирования по высоте сечения и установление особенностей напряженно-деформированного состояния этих слоев под действием нагрузки при работе на косой изгиб позволит с большей достоверностью проводить расчет на разных стадиях напряженно-деформированного состояния при проектировании клееных деревянных балок.

Ключевые слова: древесина, несущая способность, косой изгиб, деформации, напряжения, жесткость. 